\title{
A Case of Maxillary Sinusitis after Sinus Floor Augmentation
}

\author{
Eun Seok Jang, Ju Sang Lee, Yong Hyun Kim and Si Whan Kim \\ Department of Otolaryngology-Head and Neck Surgery, Hallym Sacred Hospital, Hallym University College of Medicine, Anyang, Korea
}

\author{
상악동저 보강술 후 발생한 상악동염 1 예 \\ 장은석 · 이주상 · 김용현 · 김시환 \\ 한림대학교 의과대학 한림대성심병원 이비인후과학교실
}

\author{
Received December 28, 2009 \\ Revised March 11, 2010 \\ Accepted March 19, 2009 \\ Address for correspondence \\ Si Whan Kim, MD \\ Department of Otolaryngology-Head \\ and Neck Surgery, Hallym Sacred \\ Hospital, Hallym University College \\ of Medicine, 896 Pyeongchon-dong, \\ Dongan-gu, Anyang 431-070, Korea \\ Tel $+82-31-380-3842$ \\ Fax +82-31-386-3860 \\ E-mail kimswhan@yahoo.co.kr
}

Sinus floor augmentation is essential for successful dental implantation in patients with alveolar bone height less than $10 \mathrm{~mm}$. However, maxillary sinusitis has been reported to occur in $8-20 \%$ of patients after sinus floor augmentation. We present a case of maxillary sinusitis due to sequestrum of bone cement fragment into the maxillary sinus ostium after sinus floor augmentation.

Korean J Otorhinolaryngol-Head Neck Surg 2010;53:310-2

Key Words Maxillary sinusitis · Dental implants · Foreign-body migration · Complications.

\section{서 론}

상악동저 보강술(sinus floor augmentation, sinus lift) 은 성공적인 치아 임플란트 이식을 위한 술식이다. 일반적 으로 치조골의 높이가 $10 \mathrm{~mm}$ 이상이 되어야 치아 임플란트 를 이식할 수 있다. ${ }^{1)}$ 그러나 무치악(edentulous maxilla) 의 경우 상악동이 하방으로 확장되면서 치조골이 흡수되어, 치조골의 높이가 $10 \mathrm{~mm}$ 이하인 경우가 많다. ${ }^{2}$ 이런 경우 성공적인 치아 임플란트 이식을 위해서 상악동에 자가이식 편, 동종이식편, 혹은 이종이식편을 넣는 상악동저 보강술 을 시행하게 된다. ${ }^{3}$

상악동저 보강술 중 천공된 상악동 점막을 통해 이식물 주변에 발생한 염증이 상악동 내로 파급되거나, 일시적인 골막하 부종이 자연공을 폐쇄하거나, 혹은 이식물에 대한 이물반응이 상악동저 보강술 후 부비동염의 주된 원인으로 알려져 있고, 자연공 근처까지 점막을 거상한 경우에 상악 동 자연공을 막아 발생하는 경우도 있다. ${ }^{4)}$ 각각의 이식물 간에 상악동염 발생률은 차이가 없다고 알려져 있다. ${ }^{5)}$
저자들은 상악동염의 병력이 없는 환자에서 상악동저 보 강술을 위해 삽입한 이식물이 상악동 자연공을 폐색하여 발 생한 상악동염 1 예를 치험하였기에 문헌고찰과 함께 보고하 는 바이다.

\section{증 례}

50 세 여자 환자가 2개월 전부터 발생한 좌측 비강의 농 성 비루 및 비폐색을 주소로 내원하였다. 환자는 치아우식 증으로 좌측 상악의 제 1 및 2 대구치를 발치한 후, 발병 2 주 전에 치아 임플란트 이식을 위해 치조정 접근법 (crestal approach)으로 동종골(Puros ${ }^{\mathrm{TM}}$, Zimmer Dental Inc., Carlsbad, USA)을 사용하여 좌측 상악동저 보강술을 시행 한 병력이 있었다. 증상 발생 후 항생제를 복용하였으나, 상기의 증상은 호전과 악화를 반복하였다. 만성 비부비동 염, 당뇨병 및 만성 염증성 질환의 병력은 없었다. 비내시 경 검진에서 좌측 비강 점막의 부종과 좌측 중비도로부터 의 농성 비루가 관찰되었으며, 우측 비강은 정상 소견이었 
Fig. 1. Preoperative paranasal sinus CT scan. Coronal CT scan shows bony density sequestrated in the maxillary sinus ostium with soft tissue density (arrow)(A). Coronal CT scan shows bony density protruding through the sinus floor (arrowhead) (B).
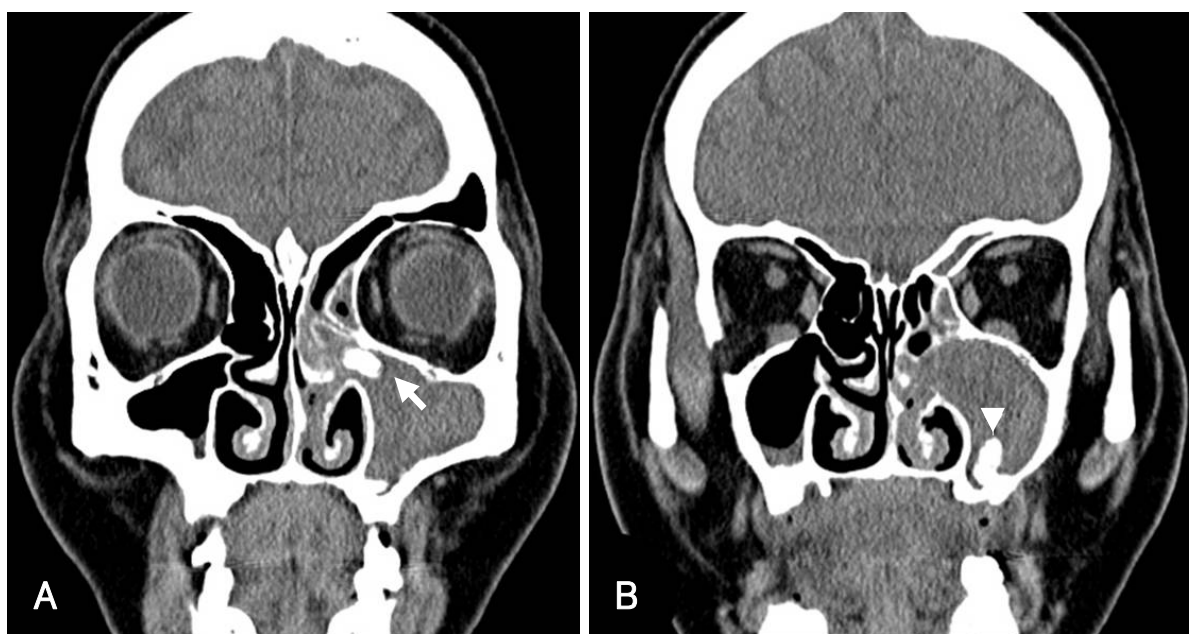

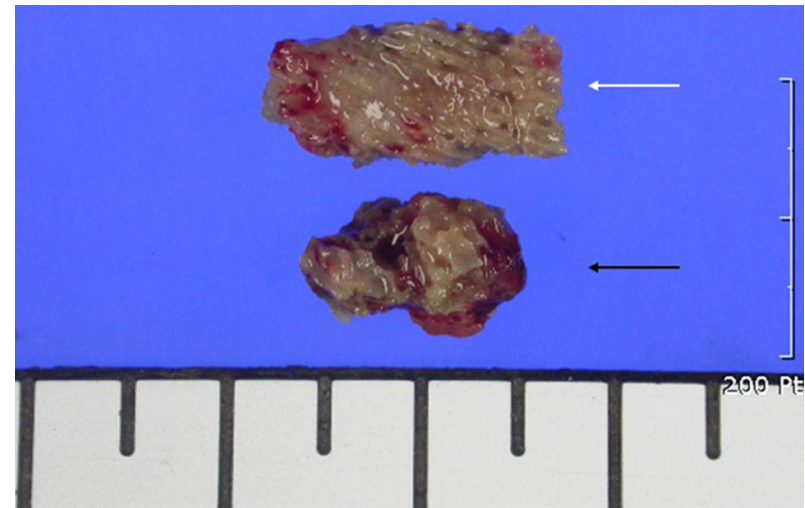

Fig. 2. Surgical specimen (white arrow: bone cement sequestrated in the sinus ostium, black arrow: bone cement at the sinus floor).

다. 부비동 전산화 단층촬영상 좌측 상악동은 골조직 음영 과 동반된 혼탁음영이 있었으며, 골조직 음영은 상악동 자 연공 및 상악동저에서 관찰되었다(Fig. 1).

상악동저 보강술에 사용된 골 시멘트 조각이 상악동 자 연공을 폐색하여 발생한 상악동염으로 진단한 후, 부비동 내시경 수술을 시행하였다. 수술 소견에서 좌측 상악동저 보강술에 사용되었던 골 시멘트 일부가 분리되어 상악동 자 연공을 막고 있었으며, 상악동 내에는 농성 분비물이 관찰 되었다. 중비도 개창술을 시행한 후, 상악동 자연공을 막고 있는 약 $15 \mathrm{~mm}$ 길이의 골 시멘트 조각을 제거하였다. 하비 도 개창술을 시행한 후, 상악동 저부의 골 시멘트를 모두 제 거했다(Fig. 2). 비강내 패킹을 시행한 후 수술을 종료하였 으며, 환자는 술 후 2 일째에 퇴원하였다. 술 후 12 개월 후 비내시경 검사에서 정상 소견을 보였다.

\section{고 찰}

상악동저 보강술은 1976년 소개된 이후 임플란트 전 술
식으로 널리 시행되고 있으며, 보강술 후 이식 성공률도 75 93\%로 비교적 높다. ${ }^{6)}$ 이는 상악동저와 치조제(alveolar ridge) 사이의 거리가 가까워 임플란트 이식이 어려운 경우 시행하며, 상악동저에 점막골막피판(mucoperiosteal flap) 을 거상한 후, 골이식 재료를 이식하는 술식이다. 측방접근 법(lateral approach) 과 치조정접근법으로 시행하며, 자가 골, 동종골, 이종골 및 합성골 등 다양한 재료를 사용한다. 이식물 간 임플란트의 이식 성공률은 차이가 있는데, 자가 골의 경우 $80 \%$, 동종골 (Puros ${ }^{\mathrm{TM}}$, Zimmer Dental Inc., Carlsbad, USA)의 경우 $100 \%$, 이종골(Bio-oss ${ }^{\oplus}$, Geistlich Pharma AG, Wolhusen, Switzerland)의 경우 96.5\%, 그 리고 합성골 $\left(\mathrm{MBCP}^{\mathrm{TM}}\right.$, Biomatlante Co., Bretagne, France) 의 경우 $92.3 \%$ 로 보고된 바가 있다. ${ }^{7)}$ 상악동저 보강술의 시행이 증가하면서, 출혈, 술 후 상악동염, 이식물의 감염, 창상 열개, 구강상악동루 등의 합병증도 증가하고 있다. ${ }^{8)}$ 특 히, 상악동염은 상악동저 보강술을 시행한 환자의 8 20\% 에서 발생한다. ${ }^{6,9)}$ 만성 비부비동염 병력이 있는 환자의 경 우에는 $50 \%$ 에서 상악동저 보강술 후 상악동염이 발생하 므로, 보강술 전에 부비동염을 치료하는 것이 권장된다. ${ }^{10)}$

상악동저 보강술의 합병증으로 발생한 상악동염을 경구 항생제만으로 치료했다는 보고가 있으며, ${ }^{11)}$ 비강점막 수축 제의 사용과, 생리 식염수로 비강을 세척하는 것이 도움이 된다고 알려져 있다. ${ }^{12)}$ 하지만, 보존적 치료에도 불구하고 증상이 호전되지 않는다면, 감염된 조직과 이식물을 제거 하기 위한 부비동 내시경 수술이나, Caldwell-Luc 수술을 시행한 후, 항생제 및 스테로이드 비강 분무제를 사용하는 것이 권장된다. ${ }^{13-15)}$ 이러한 경우에는, 치아 임플란트를 식 립할 수 없는 경우도 있으며, 식립한 임플란트를 제거하기 도 한다. ${ }^{9,10,13)}$

본 증례는 상악동의 병변이 없던 환자에서 상악동저 보 
강술 후 상악동 내로 돌출된 이식물이 분리되어 상악동 자 연공을 폐색하여 상악동염이 발생한 것으로 생각된다. 그 러므로, 일반적인 항생제 및 보존적 치료를 적용하기 어려 울 것으로 판단되어 조기에 수술적 치료를 시행하였던 증 례이다.

상악동저 보강술 이후 발생한 상악동염 환자에서 적절한 치료방법을 결정하기 위해서는 조기에 부비동전산화단층 촬영과 같은 방사선학적 검사를 시행하여 상악동 자연공을 폐색하는 원인을 확인하는 것이 필수적이다.

\section{REFERENCES}

1) Tatum OH Jr, Lebowitz MS, Tatum CA, Borgner RA. Sinus augmentation. Rationale, development, long-term results. N Y State Dent J 1993;59(5):43-8.

2) Zimbler MS, Lebowitz RA, Glickman R, Brecht LE, Jacobs JB. Antral augmentation, osseointegration, and sinusitis: the otolaryngologist's perspective. Am J Rhinol 1998;12 (5) :311-6.

3) Doud Galli SK, Lebowitz RA, Giacchi RJ, Glickman R, Jacobs JB. Chronic sinusitis complicating sinus lift surgery. Am J Rhinol 2001; 15 (3):181-6.

4) Smiler DG, Johnson PW, Lozada JL, Misch C, Rosenlicht JL, Tatum $\mathrm{OH} \mathrm{Jr}$, et al. Sinus lift grafts and endosseous implants. Treatment of the atrophic posterior maxilla. Dent Clin North Am 1992;36(1):15186; discussion 187-8.

5) Nkenke E, Stelzle F. Clinical outcomes of sinus floor augmentation for implant placement using autogenous bone or bone substitutes: a systematic review. Clin Oral Implants Res 2009;20 Supple 4:124-33.

6) Jensen J, Simonsen EK, Sindet-Pedersen S. Reconstruction of the se- verely resorbed maxilla with bone grafting and osseointegrated implants: a preliminary report. J Oral Maxillofac Surg 1990;48(1):2732; discussion 33.

7) Yu JA, Lee SM, Yoo MK, Jung UW, Kim CS, Choi SH, et al. The retrospective study of survival rate of implants with maxillary sinus floor elevation. J Korean Acad Periodontol 2009;39 (3) :293-301.

8) Zijderveld SA, van den Bergh JP, Schulten EA, ten Bruggenkate CM. Anatomical and surgical findings and complications in 100 consecutive maxillary sinus floor elevation procedures. J Oral Maxillofac Surg 2008;66(7):1426-38.

9) Timmenga NM, Raghoebar GM, Boering G, van Weissenbruch R. Maxillary sinus function after sinus lifts for the insertion of dental implants. J Oral Maxillofac Surg 1997;55 (9):936-9; discussion 940.

10) Tidwell JK, Blijdorp PA, Stoelinga PJ, Brouns JB, Hinderks F. Composite grafting of the maxillary sinus for placement of endosteal implants. A preliminary report of 48 patients. Int J Oral Maxillofac Surg 1992;21 (4) :204-9.

11) Small SA, Zinner ID, Panno FV, Shapiro HJ, Stein JI. Augmenting the maxillary sinus for implants: report of 27 patients. Int J Oral Maxillofac Implants 1993;8 (5):523-8.

12) Timmenga NM, Raghoebar GM, van Weissenbruch R, Vissink A. Maxillary sinusitis after augmentation of the maxillary sinus floor: a report of 2 cases. J Oral Maxillofac Surg 2001;59 (2):200-4.

13) Chanavaz M. Sinus graft procedures and implant dentistry: a review of 21 years of surgical experience (1979-2000). Implant Dent 2000; 9(3):197-206.

14) Misch CM, Misch CE, Resnik RR, Ismail YH, Appel B. Post-operative maxillary cyst associated with a maxillary sinus elevation procedure: a case report. J Oral Implantol 1991;17 (4):432-7.

15) Pignataro L, Mantovani M, Torretta S, Felisati G, Sambataro G. ENT assessment in the integrated management of candidate for (maxillary) sinus lift. Acta Otorhinolaryngol Ital 2008;28 (3):110-9. 